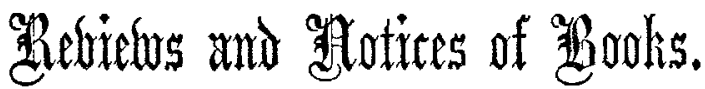

Experiences of a Civilian in Eastern Military Hospitals ; with Observations on the English, French, and other Medical Departments, and the Organization of Military Schools and Hospitals. By Peter Pincoffs, M.1., \&c. \&c. London: Williams and Norgate.

THIs is a valuable, well-written book upon a subject of undying interest. The Russian war served to bring out into disgraceful prominence the deficiencies of our hospital arrangements, whilst at the same time it brought us into close contact with another great military power whose medical service has generally been regarded as a model for the rest of Europe. Dr. Pincoffs, a man of large experience and highly-cultivated mind, was civil physician to the Scutari hospitals; and he here gives us, in a very pleasant and readable narrative, the results of his observation, together with important suggestions for the amendment of our own military medical service.

The author is a civilian, and from the unfortunate antagonism existing between the civil medical service and the military surgeons and physicians proper, his statements may, perhaps, in some quarters, be read with suspicion; but we think that his book can hardly fail to furnish all who are not blinded by professional prejudices, with a number of extremely valuable suggestions.

Dr. Pincoffs appears to be thoroughly conversant with the French and some of the other continental systems; and the portion of his work that will excite the liveliest interest is where he draws a comparison between our own hospital ar. rangements and those of our neighbours nearest the channel. He considers it desirable, amongst other things, that we should imitate them in establishing a division between the surgical and medical cases. "The entire field of medical science," he truly observes, "is so extensive, and the two branches require, as it were, a different bent of mind; so that it is but seldom that a distinguished surgeon is at the same time a good phy sician." We have some tables given to show the comparative grades of promotion and remuneration in the medical services of England, France, Austria, Prussia, and Holland, that merit, and, we hope, will receive, careful consideration; the more so as we know not, save in the present work, where we could look for trustworthy information on this important subject. Although Dr. Pincoffs has pointed out with unsparing fidelity the faults of our military medical service-although he has stated that the condition of the British army, in the first winter of the campaign, was more deplorable than even the "Times' Correspondent" represented it to be, yet he cheerfully admits that such a reformation was at length effected as to present a state of things unexampled, perhaps, in the history of war-that of our army, in the second year of a campaign, being almost exempt from disease.

A Manual of Photographic Manipulation, treating of the Practice of the Art, and its various Appliactions to Nature. By Lake Price. Foolscap 8ro, pp. 256. London: Churchill.

THE author has been long favourably known as a practical photographist, and has endeavoured in this publication to condense into the shortest space, and in the most simple form, the information which he has to offer to the reader. If he occasionally appears to be too minute in his descriptions of the various manipulations, he justifies the proceeding on the ground of the great importance of attending to minutiæ in the practice of an art, the successful pursuit of which depends upon strict attention to detail. Mr. Price has succeeded admirably in simplifying the whole process of photography, and his book will be a boon to all students in that process. The Manual is profusely illustrated with engravings, which in a marked manner facilitate the reader's appreciation of the views of the author.
British Wild Flowers. Illustrated by JOHN E. SOWERBY; the Descriptions by C. P. JoHnson. No. I. London: Sowerby: THF success of Mr. Sowerby's elegant work on the "British Ferns" has induced him to issue a cheap manual of "British Wild Flowers." The first number contains eighty excellent illustrations, accurately coloured. The descriptive portion of the publication is short and concise. This number is marvellously cheap, being issued at the low price of $3 \varepsilon$. It cannot fail of attaining an extensive circulation.

On Medicine and Medical Education. By W. T. GaIrdner, M.D., F.R.C.P., Lecturer on the Practice of Physic, Edin burgh. pp. 130. Edinburgh.

Four Letters to Sir James Clark, Bart., M.D., F.R.S., on Administrative Reform in Relation to Medical Education and the Examining Boards. By Alexander Harvey, A.M., M.D., late Lęcturer, and formerly one of the Examiners in the University of Aberdeen. pp. 80 . London: Churchill.

Remarks on the Conditions, Necessitics, and Claims of the Universities of Scotland; with an Appendix. By A Graduate. pp. 72. London : Stanford.

THese several tracts well deserve perusal at the present moment. That by Dr. Gairdner is also worthy of deeper consideration, and there is no teacher nor medical student but would be benefited by its careful study.

\section{THE NEW COLLEGE REGULATIONS.} To the Editor of THE LANCET.

SiR,-OOn all former occasions, when the Council of the Royal College of Surgeons of London have thought proper to alter their regulations, the rights of medical students who have bond fide entered the profession" have been respected; but by the new regulations they make little or no allowance for first, second, or third year's students, any more than those who have not entered the profession. It is certain that an alteration in the regulations of the College was wanted; but the rights of those who have entered the profession should be respected by the College now as before. On all former occasions those who had entered the profession prior to any alteration in the regulations have been admitted to the examination according to the regulations that existed before the alteration; but by the new regulations not even the student who has entered his third year at College will be allowed that privilege, but will be obliged to undergo the double examination, which is most unjust. Had the Council followed the example of the Apothecaries' Company, no student would have had any cause of complaint; but as it is, I have no doubt that many who have taken out their studies for the College and Hall will prefer getting their diploma in Surgery from some other College than submit to such a sudden alteration.

Knowing, Sir, that you have ever been a friend to the just claims of the student, myself and many other of my fellowstudents will be greatly obliged by your giving a place for the insertion of this letter in your valuable journal.

Macclesfield, July, 1858 I am, Sir, your obedient servant,

The Expenses of the Bonrd of Works.-It appears from a paper moved for by Mr. Butler, M.P., that the expen diture of the Metropolitan Board of Works, from Jannary lst 1856 , to Juiy 31 st, 1857 , was as follows :-Sewerage, £112,593; contingencies, $\mathfrak{L T}^{7}, 199$; establishment charges, $£ 351,659$; thus showing that the establishment charges are about 30 per cent. of the expenditure. But it appears by a note, that out of the $£ 112,593$ expended for sewage works, $£ 90,404$ were paid in respect of works contracted for and partly executed by the late Metropolitan Commissioners of Sewers. Supposing that one-half of the works charged in this sum has been executed since the lst of Jannary, 1856, when the Board commenced its duties, it will appear that the expenditure on works and contingencies has been $£ 6 \tau, 391$; while the establishment charges have amounted to $£ 35,659$, or more than 80 per cent. of the amount expended on works. The return for one year and a half exhibits the cost of the establishment at $£ 23,7,2$ per annum; the return does not give the items which consti. tute the annual charge. 